\title{
The Concept of Integration in the Jurisprudence of the European Court of Human Rights
}

\author{
Clíodhna Murphy \\ Trinity College Dublin, Ireland
}

\begin{abstract}
Integration has become a recurring theme of national immigration policies; and there has been a corresponding normative development of the concept to a certain degree in the European Union, both in soft policy and through references to integration in legally binding immigration measures. The difficulty in defining integration is a pervasive problem encountered by lawyers and sociologists attempting to understand the phenomenon. This article argues that the development of the concept of integration by the European Court of Human Rights has an important contribution to make to the debate, with the potential to provide a legal framework within which to situate integration policies at the national and the EU level. It assesses the concept of integration employed by the European Court of Human Rights, analysing the Court's Article 8 immigration jurisprudence in terms of two core issues: first, the conception of integration employed in the jurisprudence of the European Court of Human Rights; and second, the implications of the development of the concept in terms of impacting on the right to remain in a State Party and family reunification, each a key integration issue. The article concludes that while the jurisprudence relating to what actually constitutes 'integration' is very much in its infancy, the express consideration of integration as a factor in the balancing exercise undertaken by the Court in the expulsion cases signifies the start of a normative development of the concept of integration by the European Court of Human Rights. Nevertheless, it remains to be seen whether the increased emphasis of the Court on the integration criterion in the Article 8 expulsion cases influences the Court's approach to key integration issues such as family reunification and in turn whether this filters down to legislators and policymakers at the national level.
\end{abstract}

\section{Keywords}

integration paradigm; Article 8 ECHR; European Court of Human Rights; family life

\section{Introduction}

Integration has become a recurring theme of national immigration policies; ${ }^{1}$ and there has been a corresponding normative development of the concept to a certain degree in the European Union, both in soft policy and through references to

\footnotetext{
1) For an analysis of European integration policies see for example the contributions in Elspeth Guild, Kees Groenendijk and Sergio Carrera, Illiberal Liberal States: Immigration, Citizenship and Integration in the EU (Aldershot: Ashgate 2009); see also Sergio Carrera, A Comparison of Integration Programmes in the EU: Trends and Weaknesses (Brussels: Centre for European Policy Studies 2006).
} 
integration in legally binding immigration measures. ${ }^{2}$ The difficulty in defining integration is a pervasive problem encountered by lawyers and sociologists attempting to understand the phenomenon, "hindering coherent policy development and productive public debate". ${ }^{3}$ This article argues that the development of the concept of integration by the European Court of Human Rights has an important contribution to make to the debate, with the potential to provide a legal framework within which to situate integration policies at the national and the EU level.

The Strasbourg Court has been grappling with integration issues in a different context to national and European policy-makers and legislators: that of the negative obligation of States under Article 8 not to expel long-term residents in certain circumstances; and the positive obligation of states- again under Article 8 - to authorise family reunification in certain circumstances. Attention has been focused to date on the inconsistencies and deficiencies of this jurisprudence from the perspective of immigration law generally. In contrast, the focus of this article is on illustrating the importance of this well-known body of judgments to gaining an insight into the elusive concept of integration. The article assesses the concept of integration employed by the European Court of Human Rights, analysing the jurisprudence in terms of two core issues: first, the conception of integration employed in the jurisprudence of the European Court of Human Rights; and second, the implications of the development of the concept in terms of impacting on the right to remain in a State Party and family reunification, each a key integration issue.

The jurisprudence has established that integration does not give rise to a discrete legal category: immigrants who have spent most or all of their lives in a country remain in the same broad legal category as all immigrants. Nevertheless, the Strasbourg Court now explicitly takes into account the fact of integration in determining whether an expulsion decision violates Article 8 and in this sense integration leads to an increased level of protection from expulsion. Having established these starting points, the article goes on to outline the contours of the Court's conception of integration, which emerge quite clearly from the case law. It is argued that the Court's integration paradigm appears to place the onus of integration on the migrant rather than focussing on States' responsibilities to ensuring the integration of immigrant communities. However, the aspects of

\footnotetext{
2) See generally Sergio Carrera, In Search of the Perfect Citizen? The Intersection between Integration, Immigration and Nationality in the EU (Martinus Nijhoff, 2009); see also Helene Urth, "Building a Momentum for the Integration of Third-Country Nationals in the European Union", (2005) 7 EJML 163, p. 164. See also Directive 2003/86/EC on the right to family reunification; Directive 2003/109/EC of 25 November 2003 on a long-term resident status for third country nationals who have legally resided for five years in the territory of a Member State.

3) Alistair Ager and Alison Strang, "Understanding Integration: A Conceptual Framework" 21(2)(2008) J of Refugee Studies, p. 166.
} 
integration which are emphasised, and to some extent the form of the concept itself, depend on the facts of the individual case. In addition, and even more importantly, the weight given to integration considerations in the balancing exercise undergone by the Court in each case each case is variable. This is because integration in itself is not the primary focus of the Court's reasoning. The implications of the Court's reasoning from the integration perspective remain for the moment incidental to the broader issues in these cases. This means that the impact of the Court's development of the concept of integration on the key practical issues of the right to remain in a State Party and family unity remains limited.

Finally, it is argued - by reference to the family reunification cases in particular that these cases are underscored by the wide margin of appreciation afforded to states. In the context of the admissions category, it is suggested that the difficulties of the Court in delineating the extent of the positive obligations of States under Article 8 is illustrative of the fundamental difficulties attached to using international law in the integration sphere. It thus remains questionable whether the ECHR as interpreted by the Strasbourg Court will have a meaningful impact on the integration policies of European states.

\section{Difficulties with Defining the Concept of Integration}

Integration is a contested and controversial concept, with some commentators seeing its premise as representing a rejection of diversity by migrant receiving societies. ${ }^{4}$ Integration is often associated with assimilation and discrimination, a frame of analysis which has become increasingly relevant in the context of the use of the concept of 'integration' by many European states as a norm in immigration law - a mandatory condition for entry to the state or access to social welfare and residency rights. ${ }^{5}$ At the same time however, competing narratives of integration centred on holistic, two-way conceptions of integration continue to emerge from NGOs and academics. ${ }^{6}$ The disjuncture between the way in which governments and other organisations interpret the concept of integration permeates the integration debate.

The meaning, scope and implications of 'integration' thus remain controversial. For the purposes of this article, the definition of integration employed by the

\footnotetext{
4) Elspeth Guild, The Legal Elements of European Identity: EU Citizenship and Migration Law (Kluwer Law International, 2004), p. 234.

5) Anja Wiesbrock, "Discrimination Instead of Integration? Integration Requirements in Denmark and Germany", in Elspeth Guild, Kees Groenendijk and Sergio Carrera, Illiberal Liberal States: Immigration, Citizenship and Integration in the EU (Aldershot: Ashgate, 2009), p. 299.

6) See for example Rosa DaCosta, Rights of Refugees in the Context of Integration: Legal Standards and Recommendations, UNHCR Legal and Protection Policy Research Series (UNHCR, June 2006); Alistair Ager and Alison Strang, "Understanding Integration: A Conceptual Framework" 21(2)(2008) J of Refugee Studies, p. 166.
} 
$\mathrm{EU}$ in the Common Basic Principles ("CBPs") for integration will be used as a working definition and reference point. Integration is defined as a "dynamic, twoway process of mutual accommodation by all immigrants and residents of Member States"; 7 and the CBPS also set out the basic requirements of integration: respect for the basic values of the European Union, ${ }^{8}$ including the diversity of cultures and religions; ${ }^{9}$ and a basic knowledge of the host society's language, history and institutions. ${ }^{10}$ Key integration issues are termed as including access to employment, ${ }^{11}$ education ${ }^{12}$ and access to institutions on an equal basis to national citizens ${ }^{13}$ are identified. This working definition is employed with the caveat that EU law and policy has been criticised as diverging from this inclusive model ${ }^{14}$ and it is arguable that the EU approach to integration replicates in many ways the deficits of national approaches to integration. ${ }^{15}$

\section{Interactions between Article 8 and Integration}

While immigrants' human rights are protected by various articles of the ECHR, with the Convention applying to all persons on the territory of a State Party, ${ }^{16}$ the Article 8 expulsion and admission cases involve a direct clash of immigrants' desire to reside in a State Party and States' right to control immigration and residence. These two interlinked strands of case law are directly linked to integration in different ways. The expulsion cases have largely concerned 'integrated aliens' ${ }^{17}$ and/or second-generation immigrants: migrants who have lived for a long period of time in the host country (in some cases their whole lives), whom the State is seeking to expel from its territory on public order grounds following a criminal conviction. The second category of cases relates to the positive obligations inherent in Article 8 and concerns the situation where an applicant in a Contracting State maintains that the refusal of that State to allow the entry of a member of his

\footnotetext{
7) Common Basic Principle (“CBP”) 1.

8) CBP 2.

9) $\mathrm{CBP} 8$.

10) $\mathrm{CBP} 4$.

11) CBP 3.

12) CBP 5.

13) $\mathrm{CBP} 6$.

14) Clíodhna Murphy, "Immigration, Integration and Citizenship in European Union Law: the Position of Third-Country Nationals", (2008-2009) 8(1) Hibernian LJ, p. 155.

15) Sergio Carrera and Anja Wiesbrock, Civic Integration of Third-Country Nationals: Nationalism Versus Europeanisation in the Common EU Immigration Policy (Brussels: Centre for European Policy Studies 2009).

16) Article 1 provides that "The High Contracting Parties shall secure to everyone within their jurisdiction the rights and freedoms defined in Section 1 of this Convention," thus making no general distinction between citizens and non-citizens.

17) A phrase used by Judge Morenilla in his partial dissent to Nasri v France (1996) EHRR 458 (para. 4); see also dissenting opinion of Judge Martens in Boughanemi v France (1996) 22 EHRR 228 (para. 1).
} 
family fails to respect his family life. While integration is not expressly discussed in these cases in the same fashion, family reunification is a central integration theme and these cases are thus crucial in examining integration more broadly.

\subsection{The Expulsion Cases: Developing the Concept of Integration}

It is well-established that a decision to expel a non-national from a Contracting State may raise an issue under Article 8 if it would disrupt family or private life in that State. As noted above, many of these cases which have come before the Court have concerned 'integrated' or second-generation immigrants who have lived for long periods of time in the host state. Integration has thus featured as an important part of the reasoning of the Court in the Article 8 expulsion cases. The Strasbourg Court has placed a strong emphasis on integration, in particular the social aspects of integration, in deciding whether the expulsion fails to respect the individual's private and family life. It will be shown that the Court's jurisprudence has gradually evolved to the point of assessing complex questions of the applicant's social and cultural ties and economic links to the Contracting State, in addition to the more straightforward issue of family ties.

The Court assesses these cases on a case-by-case basis rather than treating longterm immigrants as a special category whose expulsion would require exceptional circumstances. ${ }^{18}$ This case-by-case approach led to particularly haphazard results in the early cases, which was described as "a source of embarrassment for the Court" and a "lottery". ${ }^{19}$ No clear thread of logic underlining the importance either the seriousness of the offence or the applicant's degree of integration or the looseness of the family ties is apparent in these cases, with the Court emphasising different factors in each case. ${ }^{20}$ Since the 2001 judgment in Boultif $v$ Switzerland ${ }^{21}$ however, the Court has followed a more structured approach, applying a defined set of criteria to each case. ${ }^{22}$ At least three of these criteria are indirectly linked to the degree of integration of the individual in the host state: the duration of the individual's stay, his or her family situation and difficulties that would be faced by the spouse in the country of origin. This last criterion incidentally introduces a further integration dimension into the discussion (along with that of the

\footnotetext{
18) On this point, see the judgments of Judge Martens and Judge Morenilla in Nasri. It was definitively confirmed that the Court would not follow this approach in Uner $v$ The Netherlands.

19) Comments of Judge Martens in Boughanemi v France (1996) 22 EHRR 228 (para. 4).

20) Charlotte Steinorth, "Uner $v$ The Netherlands: Explusion of Long-Term Immigrants and the Right to Respect for Private and Family Life”, (2008) 8 (1) Hum Rts Law Rev 185, p. 186.

21) Boultifv Switzerland (2001) 33 EHRR 50.

22) These criteria include: the nature and seriousness of the offence committed; the duration of the individual's stay in the country from which he will be expelled; the time elapsed since the commission of the offence and the applicant's conduct during that period; the nationalities of the various persons concerned; the applicant's family situation; and the seriousness of the difficulties the spouse would be likely to encounter in the country of origin.
} 
degree of integration of the person whom it is proposed to expel) as it essentially seeks to ascertain how difficult it would be for the spouse to integrate into the country of origin. Regarding the duration of stay criterion, the Grand Chamber in Uner $v$ The Netherlands ${ }^{23}$ explained its rationale as the assumption that the longer the individual stays, the closer the ties between the individual and the host state must be. ${ }^{24}$ In addition, the Grand Chamber in Uner $v$ The Netherlands added two further criteria to the list of matters to be considered in these cases:

- The best interests and well-being of the children, in particular the seriousness of the difficulties which any children of the applicant are likely to encounter in the country to which the applicant is likely to be expelled; and

- The solidity of social, cultural and family ties with the host country and the country of destination. ${ }^{25}$

In light of the above, the Court accepted as 'self-evident' that special regard should be had to the situation to the position of immigrants who had spent all or most of their life in the host country, had been raised there and received their education there. ${ }^{26}$ The question is therefore how this 'special regard' is to be exercised, and to what extent it will impact on the outcome of cases.

In Uner then, the ECtHR placed increased emphasis on the fact of integration by including it as one of the express criteria to be applied by the courts. ${ }^{27}$ This was of course really nothing new as integration had implicitly been considered since the early cases - which looked at the links of the immigrant and their families to the host country including - inter alia - whether they were educated in the country, and the links to the country of origin including knowledge of the language and the presence of family in that country. Since Boultif, in particular, the Court had looked at the social ties which the person had established in the host country. ${ }^{28}$ However, the express recognition in Uner of a requirement to consider a

23) (2007) 45 EHRR 14.

24) Ibid., at para. 58.

25) Ibid.

26) Ibid.

27) This built in particular on the Court's judgment in Benhebba v France (Application No. 53441/99) Judgment of 10 July 2003, which considered the Boultif criteria and added that as well as these factors, the person's links with the host country where they had spent most of their life should be considered. Here, however, the ten-year exclusion from the country was found to be proportionate, with his links to the country outweighed in the balancing exercise by the severity of the offence.

28) See Benhebba v France; Radovanovic v Austria (2005) 41 EHRR 6; Keles v Germany (2007) 44 EHRR 12. This analysis of social ties in relation to second-generation immigrants and immigrants who come to the host country at a very young age is explained in Benhebba $v$ France as follows: "Added to these (Boultif) criteria, the links which these immigrants have formed with the host country in which they have spent most of their lives. They received their education there, formed most of their social ties, and so developed most of their identité propre (own identity). Born or having arrived in the host country as a 
person's social and cultural ties opens the door to a balancing exercise of a complexity which had not existed before this. The significance of this development is two-fold: it constitutes an acknowledgement that Courts can become involved in assessing integration issues and the extent of a person's integration; and also indicates the basic implications of integration in terms of the ECHR - integration has the potential to impact on the legal security of residence of certain immigrants in certain circumstances. Thym makes this point well:

\footnotetext{
The resulting proportionality test will be much more complex than in cases concerning the 'simple' protection of family life and cover criteria whose interaction is not always straightforward in a plurilateral balancing exercise. Decisive factors will include the integration into the labour market, dependence on social assistance, language skills as an indicator of social integration, criminal behaviour, and links with the country of origin or their absence and the duration of the stay in the host country. Here, the eight Boultif criteria may only be a starting point for a complex jurisprudence which the Court has only started to develop. ${ }^{29}$
}

I will now consider how integration is conceived by the Court and how the integrated status of some immigrants has affected the Court's analysis of their case in practice.

\section{The Scope and Content of the Integration Criterion}

It is clear that integration is now one of the criteria to be considered by the Court, but the question of the scope and content of the concept of integration remains. Indications as to the content of the Court's conception of integration are provided throughout the jurisprudence. Slivenko $v$ Latvia $^{30}$ - a case involving different considerations to the others under discussion here as none of the applicants had been convicted of any criminal offence - contains an interesting discussion of the applicant's integration in Latvia. ${ }^{31}$ The applicants were a family who had resided in Latvia almost all their lives but had become stateless when Latvia regained its independence in 1991, and were required to leave the country under a deportation order issued in respect of them as members of the family of a retired Russian military officer. The Court rejected the claim of the Latvian Government

result of their parent's emigration, most of their family ties are there. Some of these immigrants have not maintained any link with their country of origin except for the fact of nationality" (para. 33).

29) Daniel Thym, "Respect for Private and Family Life under Article 8 ECHR in Immigration Cases: A Human Right to Regularize Illegal Stay?” (2008) 57 Int'l and Comp LQ 87, p. 92.

30) Slivenko v Latvia (Application No. 48321/99), Judgment of 9 October 2003 (GC).

31) Daniel Thym presents an interesting analysis of Slivenko $v$ Latvia, arguing that the Court re-conceptualizes family and private life; "the Court restricts its formerly wide understanding with a new focus on the 'nuclear family' of spouses and minor children, while at the same time broadening the protective reach of Article 8 ECHR to the network of personal, social and economic relations that make up the private life of every human being." Daniel Thym, loc. cit., p. 88 . 
that the applicants had not been sufficiently integrated into Latvian society. ${ }^{32}$ The Court first observed that the applicants had spent virtually all their lives in Latvia. It also accepted that the applicants were not of Latvian origin, and that they arrived and lived in Latvia - then part of the USSR - in connection with the service of members of their family (the first applicant's father and her husband) in the Soviet armed forces. However, these factors were outweighed by the genuine and strong personal, social and economic links in Latvia. ${ }^{33}$

In conclusion, the Court found that "at all times they were sufficiently integrated into Latvian society", ${ }^{34}$ and that in the circumstances, Article 8 was breached. This view of integration suggests that integration has occurred where the immigrant or settler forges personal, social and economic ties with the host society by living among the community, being educated and working in this community. In other words, simply being in the country on a long-term basis and living and working among its citizens was seen as the main indicator of integration. The Court did not require the applicants to reject or renounce their country or language of origin in order to evidence their integration.

This approach has not been echoed in the cases involving convicted criminal offenders, as will be seen below. It should also be noted that Slivenko was also somewhat unusual in that the Court has rarely discussed 'integration' as such, but has used the vocabulary of 'ties to the host country' and 'ties to the country of origin' to assess this. Overall, the Court has viewed a number of key factors as relevant in their consideration of integration. These are: the acquisition of nationality; links to the country of nationality; language; and labour market integration.

\subsection{Attempts to Acquire Nationality}

One of the questions which the Court will ask is as to the reasons why the individual did not have nationality of the host country and most importantly, the issue of whether they entitled to nationality of the host country and if so, whether they made efforts to obtain such nationality. In Boughanemi v France, ${ }^{35}$ Court stated that the applicant "kept his Tunisian nationality and, so it would seem, never manifested a wish to become French. It is probable, as the Government pointed out, that he retained links with Tunisia that went beyond the mere fact of his nationality. Before the Commission he did not claim that he could not

\footnotetext{
32) Para. 88.

33) In the words of the Court: "the applicants also developed personal, social and economic ties in Latvia unrelated to their status as relatives of Soviet (and later Russian) military officers. This is shown by the fact that the applicants did not live in army barracks or any other restricted area, but in a block of flats in which there were also civilians. Nor did they study or work in a military institution. The first applicant was able to find employment in Latvian companies after Latvia regained its independence in 1991.”

34) Para. 123.

35) (1996) 22 EHRR 228.
} 
speak Arabic, or that he had cut all his ties with his country of birth, or that he had not returned there after his deportation." ${ }^{36}$ In Kaya, the Court did not accept the applicant's claim that even had he applied for German nationality, he would have been unsuccessful. ${ }^{37}$

This approach places great symbolic importance on the acquisition of nationality as an indicator of integration. However, it fails to recognise the reality (admittedly changing but that still persists) of migrants in countries such as France and Germany maintaining their original nationality even through to the second generation of migrants, a tradition stemming from the initial belief that such workers were temporary 'guestworkers' ${ }^{38}$

\subsection{Links to the Country of Nationality}

The Court assesses the strength of the applicant's links to the country of nationality asking questions such as: have they got family in the country of origin? Did they often return there, or holiday there? The rationale for this is that the interference with private and family life is not so drastic where the person has real links with the country of origin. ${ }^{39}$ This ties in with the consideration of the duration of the individual's stay in the host country, however - as can be seen from the cases - the fact that the applicant has lived virtually all his or her life in the host state does not always mean that the links to the country of origin have been severed in the view of the Court. The jurisprudence shows that relatively tenuous links have been seen to establish significant ties to the country of origin.

If one takes Baghli $v$ France by way of example, this becomes clear. The applicant entered France in 1967 at the age of two and, with the exception of the period he spent doing his military service in Algeria, lived there until he was excluded in 1994. He had received all his schooling there and worked there for several years. Nevertheless, the fact that he had done military service in Algeria, had been on holidays there and "never suggested that he cannot speak Arabic", coupled with his lack of desire to become French, led the Court to the conclusion that the applicant had preserved ties with his native country. ${ }^{40}$ Similarly, in Uner $v$ The Netherlands, the Grand Chamber opined that:

\footnotetext{
36) See also C v Belgium, and Baghli v France (2001) 33 EHRR 32.

Kaya v Germany, para. 64.

38) For a discussion of the long-term effects of the early policies in France and Germany, see Pascale Fournier and Gökçe Yurdakul, "Unveiling Distribution: Muslim Women with Headscarves in France and Germany", in Michael Bodemann and Gökçe Yurdakul (eds), Migration, Citizenship, Ethnos (Macmillan, 2006).

39) See C v Belgium; Dalia v France (2001) 33 EHRR 26.

40) Para. 48.
} 
while it is true that the applicant came to the Netherlands at a relatively young age, the Court is not prepared to accept that he had spent so little time in Turkey that, at the time he was returned to that country, he no longer had any social or cultural (including linguistic) ties with Turkish society. ${ }^{41}$

In short, the Court attempts to determine whether the nationality of that country is merely a legal fact or if it reflects certain emotional and social links, ${ }^{42}$ in order to ascertain whether the person has become so "estranged" from the country that they would not be able to settle there. ${ }^{43}$ On the basis of the above cases, it seems that the Court will readily imply these emotional and social links and will rarely conclude that the estrangement is so complete as to render settling in the country of nationality impossible. For the sake of completeness, however, it is necessary to refer to Mehemi v France $e^{44}$ - one of the few cases in which the Court accepted that the applicant had no links with the country of origin other than nationality. This was a somewhat exceptional situation in that the applicant had been born in France and had had French nationality until he was a year old, losing it only because his father failed to complete the correct formalities. He was also married to a French national and had three minor children of French nationality. In the circumstances, the Court was compelled to accept that he had no links with Algeria beyond nationality.

\subsection{Language}

A further subsidiary question which is linked to the consideration of the extent of the individual's ties to the host country is the extent of the individual and the affected family members' linguistic ties to the country of nationality. In many cases the Court has employed the applicant's knowledge of the language of their country of nationality as a relevant factor in the balancing process, with linguistic ties featuring in the Court's reasoning to varying effect. ${ }^{45}$ In Kaya $v$ Germany ${ }^{46}$ the applicant went to great lengths to protest that he knew no Turkish; however the Court placed importance that he had written letters to his mother from prison in Turkish, even though he insisted that he had dictated them to a cell-mate. In Beldjoudi, emphasis was placed on the fact that the applicant appeared not to

\footnotetext{
41) Para. 63. See also $C v$ Belgium.

42) Dalia v France (2001) 33 EHRR 26, para. 53. The Court concluded that as the applicant had lived in Algeria until the age of 17 or 18, for two years without her parents, she had maintained certain family relations, spoken the local language and established social and school relationships. In those circumstances, the Court concluded that her Algerian nationality was not merely a legal fact but reflected certain social an emotional links. See also Baghli v France (2001) 33 EHRR 32, para. 48; Boulchekia v France (1998) 25 EHRR 686, paras. 46 and 50.

43) Keles $v$ Germany, para. 62.

44) For the same situation with regard to nationality and links to the country of origin, see also Beldjoudi $v$ France, in which the Court also accepted that he had no links to Algeria apart from that of nationality.

45) See for example Baghli v France; Dalia v France.

46) Application No. 31753/02, Judgment of 28 June 2007.
} 
know Arabic (he had been born and educated in France) in concluding that he had no links with Algeria apart from that of nationality. ${ }^{47}$ In addition, his wife could not be expected to follow her husband to Algeria, "a State whose language she probably does not know". ${ }^{48}$ In the same vein, in Keles $v$ Germany, while the Court presumed that the applicant was familiar with the Turkish language, the applicant's children could not be expected to follow him to Turkey, ${ }^{49}$ even though they were Turkish nationals and probably spoke some Turkish as:

Even if the children should have knowledge of the Turkish language, they would necessarily have to face major difficulties with regard to the different language of instruction and the different curriculum in Turkish schools. ${ }^{50}$

In these circumstances, Article 8 was violated by the applicant's expulsion..$^{51}$

\subsection{Labour Market Integration}

Interestingly, in a number of cases the Court has looked at the extent of the applicant's integration into the labour market of the host country thus bringing economic links into the equation. The Court often takes into account whether a person had worked in the host country as part of their ties to the host country. ${ }^{52}$ In Uner, the Grand Chamber considered whether the applicant who had lived in Germany since age twelve had integrated into the labour market. ${ }^{53}$ In Kaya $v$ Germany, the Court considered that even though the applicant had been born and spent all his life in Germany, it could not overlook the fact that he was not integrated into the labour market as had never worked, but lived off money extorted from his former partner. ${ }^{54}$ Finally, as pointed out above, the fact that the husband/father has been working in Latvian companies post-independence was also considered to be an indicator of integration in Slivenko $v$ Latvia. ${ }^{55}$ On one level, this is an interesting endorsement of inclusion in the labour market as an important instrument of integration and recognises to an extent that occupational

\footnotetext{
47) Para. 77. See also the discussion of Beldjoudi at note 40 above.

48) Para. 78.

49) The applicant's spouse, however, was Turkish and having arrived in Germany at the age of ten, it was "assumed that she has sufficient links which would allow her to re-integrate into Turkish society" (para. 63).

50) Para. 66.

51) For similar reasoning, see (as discussed above) Amrollahi, in which it was accepted that the applicant's mother tongue was Farsi however the Court concluded that in spite of this the applicant could not be considered to have maintained strong ties to Iran. In addition, and most significantly, the wife spoke none of the language.

52) See for example C v Belgium; Baghli v France. However, it was not a significant factor in either of these cases and no violation of Article 8 was found in either case.

53) Para. 65.

54) Ibid.

55) Application No. 48321/99, Judgment of 9 October 2003 (GC).
} 
or economic ties form a part of integration. However, it seems unfair to consider this in the abstract without looking at the background causes of unemployment and marginalisation. In addition, it seems that this consideration carries more weight in its negative sense as further illustration of the lack of contribution which the applicant makes to the host society: there are few examples of where positive engagement in the labour market was seen as a significant factor which rendered the individual more integrated and thus more difficult to remove from the host country. ${ }^{56}$

\section{An Emerging Integration Paradigm}

The above analysis reveals a specific conception of integration which appears to be a composite of strong links to the host country and an absence of strong links to country of origin. The Court is involved in a double-sided inquiry looking at two fundamental questions:

1. how integrated is the applicant and his family in the host country and to what extent does the expulsion consequently interfere with private and family life in that country; and

2. how difficult would it be for the applicant and his family to re-integrate into the country of nationality?

This approach would seem to require migrants to relinquish the identity of their country of origin in order to secure their place in the host society. This is problematic from a number of perspectives. First, it runs contrary to modern conceptions of integration which stress that immigrants are entitled to maintain their cultural and linguistic identity. ${ }^{57}$ In terms of international human rights law, this view of integration would appear incompatible with - inter alia - the rights of

\footnotetext{
56) In $C v$ Belgium the Court acknowledged that the applicant had established social ties in Belgium, amongst other things by working there for a number of years (para. 32). However, this was outweighed by the seriousness of the offences in question and his persisting links to Morocco (para. 34 and 35). However, see Boultif $v$ Switzerland, where the applicant had worked as a painter and at various other jobs and had the possibility of further employment. This, along with his exemplary conduct in prison, mitigated fears that he constituted a danger to public order and security for the future (para. 51). Similarly, in Keles a violation of Article 8 was found, and the fact that he had been employed for a certain period of time in Germany was referred to, although this was not considered by the Court as one of the particular factors which leaned in favour of the applicant.

57) See Council of Europe, White Paper on Intercultural Dialogue (2008), p. 6; UNHCR's definition of integration as set out in UNHCR Executive Committee, Conclusion on Local Integration (No. 104 (LVI) 2005), preamble and (k); and in the EU sphere, "Communication from the Commission to the Council, the European Parliament, the European Economic and Social Committee and the Committee of the Regions, Third Annual Report on Migration and Integration" (Brussels 11.09.2007, COM (2007) 512 final), p. 3 .
} 
minorities as guaranteed by Article 27 of the International Covenant of Civil and Political Rights and the prohibition of racial discrimination in CERD. ${ }^{58}$ On a practical level, it also fails to recognise the increasing reality of dual nationalities and transnational belonging and identities. ${ }^{59}$

Another conclusion which follows on from this is that the ECtHR places the onus of integration squarely on the migrant. The migrant as seen as the sole agent of integration with responsibility for establishing links with the host country. This is clear particularly in relation to the Court's consideration of an individual's integration into the labour market. The State is not seen as having any responsibility for undertaking to integrate the person into the fabric of the host society. This is partly explicable by the fact that the Court focuses on social and personal integration. However, for a different slant on this question, see the comments of Judge Morenilla in his partial dissent in Nasri v France:

\begin{abstract}
A State which, for reasons of convenience, accepts immigrant workers and authorises their residence becomes responsible for the education and social integration of the children of such immigrants as it is of the children of its 'citizens'. Where such social integration fails, and the result is antisocial or criminal behaviour, the State is also under a duty to make provision for their social rehabilitation instead of sending them back to their country of origin, which has no responsibility for the behaviour in question and where the possibilities of rehabilitation in a foreign social environment are virtually non-existent.
\end{abstract}

On this view, the Court through these judgments allows Governments to abdicate their responsibility for education and social integration to a State in which the person concerned has, in most cases, never lived or lived for a very short period of time. However, to follow Judge Morenilla's reasoning would involve the Court in complex issues of social, economic rights and social exclusion, a course which it would be unlikely to favour. In this way, the cases under discussion arguably serve to highlight the limitations of reliance on civil and political rights to deal with what at root may be social and economic problems. ${ }^{60}$ The rather onesided conception of integration being developed by the Court also constitutes a

58) In relation to Article 27 of the ICCPR and integration, see the Concluding Observations of the UN Human Rights Committee in relation to Albania (E/C.12/ALB/CO/1, 24 November 2006 para. 21); Germany (E/C.12/1/Add.68, 24 September 2001, para. 21); and Greece (E/C.12/1/Add.97, 7 June 2004, para. 18). In relation to CERD, the UN Committee for the Elimination of Racial Discrimination is at pains to emphasise that integration does not imply or allow for forced assimilation (see the Concluding Observations of the Committee in relation to Turkmenistan (CERD/C/TKM/CO/5, 27 March 2007), Germany (CERD/C/DEU/CO/18, 21 August 2008) and Japan (CERD/C/304/Add.114, 27 April 2001)). Furthermore, integration policies should not discourage members of minority groups from expressing their culture (Concluding observations relating to Denmark (CERD/C/DEN/CO/17, 19 October 2006)). 59) On transnationalism and dual citizenship, see for example Nancy Poner, "Engagement Across National Borders: Then and Now", (2006-2007) 75 Fordham L Rev 2483; and Linda Bosniak, "Multiple Citizenship and the Postnational Transformation of Citizenship", (2001-2002) 42 Va J Int'l L 979. p. 981.

60) Ann Sherlock makes this point well in her commentary on the Article 8 cases, suggesting that the applicants in these cases perhaps emphasise purely family life as problems of social exclusion and high 
point of divergence from most definitions of integration, which emphasise the "two-way" nature of the integration process. The definition of integration contained in the CBPs and set out above, for example, emphasises the responsibilities of the host state to ensure access to education, citizenship and the institutions of the host society, as well as the individual migrants' responsibility in the integration process. This divergence stems from the context in which the Court is considering the concept of integration: that of the proposed deportation of individuals.

\section{The Prominence of the Dissenting Judgments in the Article 8 Cases}

The comments of Judge Morenilla quoted above form part of the strong line of dissents which have characterised the Article 8 immigration case law since its inception. One of the distinctive features of this jurisprudence is the high degree of disagreement between the judges of the Strasbourg Court on fundamental aspects of the legal reasoning to be employed in determining these cases. In the early cases, the divisions centred round two fundamental points. The first of these was the uncertainty caused by adopting a case-by-case approach and the unpredictability this was causing. This has been remedied to a certain degree by the development of the Boultif criteria as discussed above. The second, more fundamental, area of disagreement concerned the correct approach to the legal status of long-term immigrants in these circumstances, with a number of judges passionately arguing that such individuals should be protected against deportation save in the most extreme circumstances. Over ten years since the first wave of cases, it now appears to be settled that this will not be the approach taken by the Court, with the Court's reasoning proceeding on the assumption that long-term immigrants do not form a discrete legal category.

More recently, the case law remains characterised by deep disagreement. In the Grand Chamber's judgment in Uner, the three dissenting judges (Judges Costa, Zupancic and Turmen) found in contrast to the majority that an assessment of the criteria pointed to a violation of Article 8. This is illustrative of the new difficulties posed by the development of a set of criteria without a clear indication of the relative weight of these criteria: a key issue which is discussed further in the next section. More fundamentally, the minority opinion referred back to the old question of the status of long-term residents, arguing that "foreign nationals - in any case those who, like Mr Üner, have been residing legally in a country - should be granted the same fair treatment and a legal status as close as possible to that accorded to nationals". ${ }^{61}$ The minority further argues that the majority judgment

unemployment may make somewhat unusual any cases where 'private life' is the dominant feature. See Ann Sherlock, loc. cit., p. 6.

${ }^{61)}$ Minority opinion, para. 5. 
fails to construe Article 8 in light of other international texts dealing with the rights of long-term immigrants. ${ }^{62}$ This continuing debate over such a foundational issue indicates the indeterminacy of international law relating to the legal status and rights of non-citizens.

\section{The Relative Weight of Integration in the Balancing Exercise}

Leaving aside for a moment the precise scope and meaning of the integration criterion, it is unclear how much weight it will actually be given in the balancing exercise undertaken by the Court in each case. The failure to address this lacuna has been seen as one of the major failings of the Uner judgment. ${ }^{63}$ One of the key factors which may tip the balance in favour of the State is the severity of the offence in question. In Boulchekia $v$ France, ${ }^{64}$ the fact that the applicant had been living in France since the age of two, and had received all his education in France was outweighed by the severity of the crime of aggravated rape which he had committed as a minor, outweighed this. ${ }^{65}$ The Court has viewed drugs offences as particularly serious, affording governments a considerable margin of discretion in dealing with drug offenders by deportation. ${ }^{66}$ This approach is perhaps understandable, as some of these cases involve individuals who clearly pose a threat to public security and order and if States could expel citizens who had committed similar offences, they most probably would.

However, the severity of the offence has not consistently trumped the other considerations. If we compare a number of judgments this becomes apparent. In Mehemi $v$ France, the applicant received a permanent exclusion order after being convicted of cannabis dealing - a serious crime in the view of the Court. However, he had been born in France and had two French children and an Italian wife. It was found that, despite the severity of the offence, his family life would be disproportionately interfered with by the expulsion. In contrast, in Baghliv France the severity of the offence (the 'severity' of which was questionable: the applicant

62) These texts included the Conclusions of the Presidency of the Tampere European Council on 15 and 16 October 1999; The Council of Europe Committee of Ministers Recommendation Rec(2000)15, Parliamentary Assembly Recommendation 1504 (2001) and Committee of Ministers Recommendation $\operatorname{Rec}(2002)$; and the 1989 United Nations Convention on the Rights of the Child.

63) See Charlotte Steinorth, loc. cit.

64) Boulchekia v France 1997-I 47; (1998) 25 EHRR 686.

65) See also Boughanemi where the serious nature of the offences in question (including living on the earnings of prostitution with aggravating circumstances) was taken into account. Conversely, in Moustaquim, the Court emphasised the minor nature of the offences in question in deciding that the expulsion would breach Article 8 (para. 44). In Ezzhoudiv France, the offences were similarly minor, and this played a large part in the reasoning of the Court.

66) The Court has expressed the view that "In view of the devastating effects drugs have on people's lives, the Court understands why the authorities show great firmness to actively contribute to the spread of this scourge" (Amrollahi v Denmark, para. 37); see also for example Dalia v France, para. 92. 
had been sentenced to three years imprisonment, two of which were suspended, for dealing in a small quantity of heroin) was not similarly outweighed by the other circumstances of the case, even though, as in Mehemi, the applicant had entered France aged two, and "his main family and social ties are in France". ${ }^{67}$ The Court laid emphasis that in this case the exclusion was for the determinate period of ten years, and thus would constitute less of an interference with the applicant's rights. ${ }^{68}$ The real difference between these two cases appears to be the family status of the applicant: the applicant in Baghli was unmarried and had no children. Nevertheless, the family status of the applicant will not always be determinative either. For example, in Uner the applicant had a Dutch partner and two sons in the Netherlands, with Dutch nationality. However, the Court did not accord as much weight to this as it had in previous cases, adopting a rather dismissive approach to the issue of the applicant's family. ${ }^{69}$

One of the outstanding issues in relation to this case-law is thus the relative weight of the various factors. While integration is an important factor, it has been seen that it is often outweighed by the seriousness of the crime or the situation of the other members of the family. Many of the inconsistencies in the case-law arise from the ad hoc approach to the balancing exercise undertaken in each case, to the extent that:

\footnotetext{
The present approach of the ECtHR, ..., leaves both prospective applicants and national authorities with little guidance as to whether an expulsion of a long-term immigrant will be deemed a proportionate measure. It would thus be preferable for the ECtHR to take a clear stance as to whether it gives primary significance to the legitimate interests of States in securing public order or to the right of long-term immigrants to remain in their host country. ${ }^{70}$
}

If the Court were to assign greater weight to the criterion of "the solidity of social, cultural and family ties with the host country and the country of destination", long-term immigrants would almost certainly enjoy greater security of residence in the host country.

\subsection{The Admission Cases: Family Reunification}

The typical admission case has concerned the situation where an applicant in a Contracting State maintains that the refusal of that State to allow the entry of a

\footnotetext{
67) Para. 48.

68) Judges Costa and Tulkens issued strong dissents on this point, noting that ten years is long enough for a person's family and social life in the host country to be obliterated.

69) The Court remarked that: "The Court concurs with the Chamber in its finding that at the time the exclusion order became final, the applicant's children were still very young - six and one and a half years old respectively - and thus of an adaptable age (see paragraph 46 of the Chamber judgment). Given that they have Dutch nationality, they would - if they followed their father to Turkey - be able to return to the Netherlands regularly to visit other family members residing there (para. 64).

70) Charlotte Steinorth, loc. cit., p. 196.
} 
member of his family (most often a child) fails to respect his right to family life. In conceptual terms, the distinguishing feature of these cases is therefore that they concern a positive obligation of the State rather than the negative obligation at play in the expulsion cases. As the Court has reiterated:

\begin{abstract}
... the essential object of Article 8 is to protect the individual against arbitrary action by the public authorities. There may in addition be positive obligations inherent in effective 'respect' for family life. However, the boundaries between the State's positive and negative obligations under this provision (art. 8) do not lend themselves to precise definition. The applicable principles are, nonetheless, similar. In both contexts regard must be had to the fair balance that has to be struck between the competing interests of the individual and of the community as a whole; and in both contexts the State enjoys a certain margin of appreciation. ${ }^{71}$
\end{abstract}

This passage suggests that the principles to be applied in relation to the negative and positive obligations contained in Article 8 are broadly similar. In the early admission cases in particular, however, the Court took a very restrictive approach towards applicants making this type of claim, affording states a wide margin of appreciation in determining whether a positive obligation existed at all. The Court stated in Abdulaziz, Cabales and Balkandali, the first of these cases, that:

as far as positive obligations are concerned, the notion of 'respect' is not clear-cut: having regard to the diversity of the practice followed and the situations obtaining in the Contracting States, the notion's requirements will vary considerably from case to case. ${ }^{72}$

The jurisprudence of the Court shows that the State's right to control the entry of non-nationals into its territory will rarely be out-weighed by the circumstances of the individual applicants. First, the Court has been clear in its position that Article 8 does not impose on a State "a general obligation to respect the choice by married couples of the country of their matrimonial residence and to authorise family reunion in its territory" ${ }^{73}$ In assessing the circumstances of the applicants, the Court will consider whether admission is the only way to develop true family life: are there are insurmountable obstacles to setting up family life in the country of origin? This is a high hurdle for applicants to overcome, as illustrated by Gul $v$ Switzerland ${ }^{74}$ and the subsequent case of Abmut $v$ The Netherlands. ${ }^{75}$ In the

\footnotetext{
71) Abdulaziz, Cabales and Balkandali v United Kingdom (1985) EHRR 471, para. 67.

72) Para. 67. Essentially, as Warbrick observes, the Court collapses the examination of whether there is a positive obligation under Article 8(1) with the question of whether it has been breached (which is an Article 8(2) matter), resulting in incoherence. Warbrick, p. 39.

73) Abdulaziz, Cabales and Balkandali v United Kingdom (1985) EHRR 471; Gul v The Netherlands (1996) 22 EHRR 93; Ahmut $v$ Netherlands (1996) 24 EHRR 62; Sen $v$ The Netherlands Application No. 31465/96, Judgment of 21 December 2001.

74) (1996) 22 EHRR 93. It is particularly difficult for applicants to succeed where the separation was caused by a deliberate and voluntary decision on the behalf of the parent or parents, as was the case in Ahmut.
}

75) (1996) 24 EHRR 62. 
controversially harsh decision in Sen, the Court found that while the circumstances of the family in question were compelling "very difficult from the human point of view", ${ }^{76}$ there was no such obligation in this case as there were "strictly speaking, no obstacles preventing them from developing family life in Turkey". ${ }^{77}$ A similar approach was taken in Abmut $v$ The Netherlands, ${ }^{78}$ in which the father had actually obtained Dutch nationality. ${ }^{79}$

It seems that one circumstance in which the Court will find that insurmountable obstacles exist to settling in the country of origin is where the applicant(s) have started a family in the host country and other children have been born or substantially brought up in that country. Here the Court acknowledges that the State's decision effectively requires the applicants to choose between their children in the host country and those in the country of origin, compelling an impossible choice which does not respect the applicants' right to family life. ${ }^{80}$ This formed the basis of the reasoning of the Court in Sen $v$ The Netherlands ${ }^{81}$ and Tuquabo-Tekle $v$ The Netherlands, ${ }^{82}$ which seemed to signal a shift towards a less restrictive attitude of the Court towards these cases. ${ }^{83}$ However, the limited number of cases which make it past the admissibility stage illustrates how difficult it remains to succeed in these cases. ${ }^{84}$

\section{Limited Consideration of Integration Issues in the Family Reunification Context}

Integration is not as significant an issue in the admission cases as in the expulsion cases considered above. This is logical as the child has not, for the most part,

\footnotetext{
76) Para. 42.

77) Para. 42. In a strong dissenting opinion, Judge Martens criticised what he viewed as the artificial distinction drawn by the majority between positive and negative obligations, and concluded that the interference with family life in this case was disproportionate and violated Article 8, particularly as it effectively required the parents to chooses between renouncing their son and renouncing their daughter who was settled in Switzerland. In his view, there had to be a limit to the Court's deference to domestic immigration law and policy (para. 9).

78) (1996) 24 EHRR 62.

79) There were four dissenting judges in this case, including Judge Valticos who stopped just short of accusing the Dutch government of racism, given that the father in this case was a Dutch national.

80) Sen $v$ The Netherlands, para. 41.

81) Application No. 31465/96, Judgment of 21 December 2001.

82) Application No. 60665/00, Judgment of 1 December 2005.

83) See Nicola Rogers, "Immigration and the European Convention on Human Rights: Are New Principles Emerging?", (2003) Eur Hum Rts L Rev 53, p. 64, where the author expresses the opinion that the Sen case signalled a "move away from state interests engendered by a greater emphasis on the need to fulfil positive as well as negative obligations under Article 8".

84) See for example Benamar $v$ the Netherlands (dec.), Application No. 43786/04, 5 April 2005; I.M. v. the Netherlands (dec.), Application No. 41266/98, 25 March 2003; and Chandra and Others $v$ the Netherlands (dec.), Application No. 53102/99, 13 May 2003.
} 
entered the receiving country yet and so no question of his or her integration could arise. The Court considers the extent of the child's "cultural and linguistic links" to the country of origin in determining the viability of developing family life in that country. ${ }^{85}$ It also considers the child's degree of dependence on the parents, ${ }^{86}$ and in this context, the age of the children may be an important factor. ${ }^{87}$ Interestingly however (and as touched upon in the previous paragraph), in cases of split families where there are children which have been brought up in the host country, the Court may also consider their degree of integration in the host country in order to ascertain the impact on them of moving to the country of origin to join the other family members. In Sen $v$ the Netherlands, the Court considered that the two children who had been born and grown up in the Netherlands and were receiving their schooling there had few or no links to the country of origin aside from the legal fact of nationality, and in these circumstances the most appropriate way to develop true family life was to allow the entry of the son who was in Turkey. ${ }^{88}$ In this limited sense, there is a certain degree of overlap here with the expulsion cases considered above.

It seems that it is only in a very narrow set of circumstances that the Court will compel a State to authorise family reunification on the basis of Article 8. Furthermore, even though the Court has insisted that the same principles are applicable in the case of the negative and positive obligations under Article 8, it is clear that the Court is reluctant to first of all find that a positive obligation exists at all and secondly that the positive obligation is breached. This is consistent with the general observations made above in relation to the difficulties inherent in identifying and enforcing positive obligations in international law. Overall, my analysis of the family reunification judgments of the ECtHR confirms that in the specific field of family reunification, States are relatively unconstrained by the ECHR in their formulation of law and policy, and - more generally - that States have a wide margin of appreciation in matters relating to the entry and residence of non-nationals.

As noted above, the Article 8 case-law has been criticised from both within the Court itself and by academic commentators for its incoherence and instability. ${ }^{89}$ These difficulties have arguably stemmed from the high degree of deference

\footnotetext{
85) Gul, para. 42; Ahmut, para. 69; Sen, para. 37.

86) See for example Sen $v$ The Netherlands, para. 37.

87) See Tuquabo-Tekle $v$ The Netherlands, para. 49, where it is stated that "The Court has indeed previously rejected cases involving failed applications for family reunion and complaints under Article 8 where the children concerned had in the meantime reached an age where they were presumably not as much in need of care as young children and increasingly able to fend for themselves". These included Benamar $v$. the Netherlands, I.M. v. the Netherlands and Chandra and Others v. the Netherlands discussed above.

88) Para. 40.

89) In addition to the comments of the dissenting judges referred to above, see Catherine Dembour, "Human Rights Law and National Sovereignty in Collusion: The Plight of Quasi-nationals at Strasbourg", (2003) 21 Netherlands Quarterly of Human Rights, p. 63.
} 
shown to domestic immigration policy in the judgments of the Court, which has led to conceptual confusion to the point where "it is difficult to extrapolate clear principles identifying the application of Article $8 " .{ }^{90}$ States are thus free to decide on the most appropriate way to deal with the key integration issue of family reunification, providing they stay within the generous margin of appreciation delineated by the Court in Sen and Tuquabo-Tekle. This is perhaps indicative of the broader difficulties faced when applying international law in the integration context. Integration is by its nature an area involving the progressive realisation of rights, of positive rights involving complex and delicate issues of social policy closely related to issues of national identity and sovereignty. International law's focus on negative obligations of States and leaving States room to manoeuvre arguably thus has a limited application in this context.

\section{Conclusions}

The readiness of the Court in recent cases to explicitly protect long-term residents under the heading of private life involves the Court in a complex and nuanced balancing exercise which includes integration as one of the express criteria to be considered by the Court. This makes explicit the integration analysis in which the Court had been implicitly engaging since the early cases. While the jurisprudence relating to what actually constitutes 'integration' is very much in its infancy, the implications of this move extends beyond the circumstances of the applicants in these cases and signifies the start of a normative development of the concept of integration by the European Court of Human Rights. This constitutes a valuable, legal, contribution to the emerging discourse on the nature, scope and implications of the integration of immigrants, all the more so given that the increasing trend across European states to use the concept of integration in a negative sense as a condition of citizenship and as a barrier to entry for immigrants and their family members.

Nevertheless, it remains to be seen whether the increased emphasis of the Court on the integration criterion in the expulsion cases influences the Court's approach to key integration issues such as family reunification and in turn whether this filters down to legislators and policymakers at the national level. In particular, the impact of the developing concept of integration on the outcome of the expulsion cases is variable and in some cases unclear, as the integration criterion is only one element of a complex balancing exercise undertaken by the Court.

In addition, it has been seen that the specific context in which the Court considers integration has led to some differences in the emerging integration

\footnotetext{
90) Nicola Rogers, "Immigration and the European Convention on Human Rights: Are New Principles Emerging?”, (2003) Eur Hum Rts L Rev 53, p. 53.
} 
paradigm employed by the Court and that put forward by the EU CBPs, for example. The one-sided approach of the Court to the notion of 'integration', placing the onus of integration principally on the individual concerned, has been criticised in this article.

Finally, as the admissions cases clearly demonstrate, the Court continues to operate within the restraints of Article 8 and in the awkward space between international obligations and states' margin of appreciation in immigration matters, which raises the question of how far the ECtHR can hope to influence state practice in this sphere, particularly where the circumstances relate to positive obligations of States. 